\title{
Classroom Action Research: Measuring Integration of Character Education in Language Learning
}

\author{
Titim Eliawati \\ Sosial Science and Education Faculty \\ Universitas Potensi Utama \\ Medan, Indonesia \\ titim.eliawati@gmail.com / titim@potensi-utama.ac.id
}

\author{
Dina Irmayanti Harahap \\ Social Science and Education Faculty \\ Universitas Potensi Utama \\ Medan, Indonesia
}

\begin{abstract}
Language teachers are supposed to understand how to integrate character education into language learning in a class. On the other hand, it is an important issue for teacher to measure character values that student absorbed and practiced in daily life. There are many methods available for teachers when integrating character values into learning. The problem is which method provides most results of integrating character values into the classroom learning. The study aims to emphasize the use and analysis the implementing of classroom action research method as one method in integrating character values. The study focuses on class action research used in integrating character education in language learning. The research was a continue research on earlier character education relate to culture and teacher leadership. It conducted at a vocational high school where character values used as culture in the school. The finding obtained was that classroom action research became one right method of finding the classroom learning methods that used to integrate character values into language learning.
\end{abstract}

Keywords-character education; class action research

\section{INTRODUCTION}

The Indonesian government for the past few years has focused on implementing character education in schools. This occurs as a result of the declining character of the Indonesian young generation whose facts could be seen from various media reports both online and in print [1]. Research on integrating character education into classroom learning has carried out to support policies issued by the Ministry of National Education and Culture - Republic of Indonesia. The school also needs justification for the results of research conducted in the field, both those conducted by academics or those conducted by teachers or practitioners.

These demands encourage teachers in creating creative learning strategies that are interesting in the classroom. The teacher's action in the class is to integrate the child's character in an integrated intellectual, moral and physical development [2]. The teacher gives habituation to children every day when at school. The school implements 10 characters value in English learning activities as implementation of the syllabus [3].

One approach to implementing character education in schools is the integration approach [4]. The new research, published in 2018, stated that creativity in teaching techniques (pedagogics) significantly increases English learning performance, creativity, and student motivation [5]. The values of character education in English subjects are friendly, caring, social, curious, democratic, independent, and hardworking, disciplined, and enjoy reading. The values of character education can be instilled in students by learning contextual English. The characteristic English learning procedure is to make students construct English knowledge actively, gain knowledge through experience, discuss in groups, and work in groups. In addition, the teacher presents the model as an example of learning, reflecting at the end of the meeting, and conducting an assessment process [6].

Classroom Action Research (CAR) methods are often used to improve learning quality in the classroom [7]. CAR helps teachers to solve problems met in the classroom. With various weaknesses and strengths, CAR is a method that is wellknown to teachers, including in Indonesia. Teacher did CAR in order to retrospect himself so that his ability as a teacher could be improved [8].

One of the subjects obtained by students in the school where the research took place was the Maritime English course. This subject is a challenge for English proficiency teachers. The school's vision expects their alumni are able to speak English. Therefore, researchers focus on the process of integrating character education in learning English Specific Purpose for Maritime. In the study, researchers decided to use CAR, because the previous study showed several data about teacher leadership in the classroom related to student character building [9]. Based on the results of observations in the classroom, the learning method used by most teachers in the school is the explanation method. This method is very quick to cause boredom for students, if student passion is not high. By using the CAR method, researchers can use several learning methods used by partner teachers in the classroom. Thus the stages of CAR to the evaluation and reflection can help researchers to measure whether the integration process of character education occurs as expected or not.

\section{LITERATURE REVIEW}

\section{A. Classroom Action Research}

Classroom Action Research (CAR) is one of the efforts of teachers or educational practitioners to try out innovative learning in the form of various activities carried out to improve the learning quality in the classroom. CAR focuses 
on class or teaching and learning processes that occur in class, not on class intake (syllabus, material, etc.) or output (learning outcomes). CAR must focus or about things that happen in the classroom. CAR is research that combines research procedure with substantive action, an action carried out in the discipline of inquiry, or an attempt by someone to understand what is happening, while being involved in a process of improvement and change [10].

In qualitative research, such as CAR, paradigms are sometimes referred to constructivist approaches, or naturalistic approaches, or interpretative approaches, or post positive approaches [11]. Action research studies are most similar to mixed method designs, because action research studies often exploit quantitative as well as qualitative data. The only real difference between the two is the basic purpose of his research [12].

CAR can restore teacher confidence, and thus restore selfesteem, or self-respect of teachers [13]. Teachers who have started doing CAR in their classes increasingly see how big the gap between idealism as a good teacher and their daily practices in the classroom. There are 4 types of action research, namely: (1) teacher action research as a researcher, (2) collaborative action research, (3) integrated simultaneous action research, and (4) experimental social action research [14]. CAR can bridge the gap between educational theories and practice [15]

\section{B. Integration of Character Education}

In the frame of reference for character education issued by the Directorate of Labor of the Directorate General of Higher Education Ministry of National Education in 2010, it explained that in principle, character development was not included as a subject but integrated into the subjects, selfdevelopment and culture of the education unit. Therefore educators and education units need to integrate the values developed in character education into the existing syllabus curriculum.

Integrated character education in the learning process as introduction of values, facilitation of an awareness of importance values, and the internalization of values into the behavior of everyday students through a learning process that takes place both inside and outside the classroom in all subjects. Thus, learning activities, in addition to making students master competencies (material) that targeted, are also designed and carried out to make students know, realize/ care, and internalize values and make them behavior. Characterized English learning procedure is to make students construct English knowledge actively, gain knowledge through experience, discuss in groups, and work in groups. In addition, the teacher presents the model as an example of learning, reflecting at the end of the meeting, and conducting an assessment process [6].

\section{DISCUSSION}

This article discussed the methods used in the research. As discussed in Part I that we use CAR with three learning methods, each of which applies two cycles. The subject that gets treated was English for Specific Purpose for Maritime.
The subject used in the classroom based on a syllabus shared by the school. Based on the results of discussions with partner teachers, it decided that the material used in the classroom in this study were (1) job responsibilities on board; (2) human behavior in emergencies; (3) communication related to crowd and crisis management in an emergency. There were three characters integrated in the class, namely responsibility, discipline and leadership, and communication. In brief, it could be seen in Table 1 as follows.

TABLE 1. BASIC COMPETENCES AND STUDENT CHARACTERS

\begin{tabular}{|c|c|c|c|}
\hline $\begin{array}{c}\text { Basic } \\
\text { Competencies }\end{array}$ & $\begin{array}{c}\text { Character } \\
\text { Developed }\end{array}$ & Subject Topic & $\begin{array}{c}\text { Learning } \\
\text { Methods }\end{array}$ \\
\hline $\begin{array}{c}\text { Job } \\
\text { Responsibilities }\end{array}$ & $\begin{array}{c}\text { Responsibiliti } \\
\text { es }\end{array}$ & $\begin{array}{c}\text { Watch Keeping } \\
\text { and Crew Roles }\end{array}$ & Discussion \\
\hline $\begin{array}{c}\text { Human } \\
\text { Behavior In } \\
\text { Evergencies }\end{array}$ & $\begin{array}{c}\text { Discipline and } \\
\text { Leadership }\end{array}$ & $\begin{array}{c}\text { The } \\
\text { Organizational } \\
\text { Of A Ship Crew }\end{array}$ & $\begin{array}{c}\text { Problem Based } \\
\text { Instruction }\end{array}$ \\
\hline $\begin{array}{c}\text { Communication } \\
\text { Related To } \\
\text { Crowd And } \\
\text { Crisis }\end{array}$ & $\begin{array}{c}\text { Communicati } \\
\text { on }\end{array}$ & $\begin{array}{c}\text { Communication } \\
\text { At Sea }\end{array}$ & Command Style \\
Management In & & & \\
An Emergency & & & \\
Situation & & & \\
\hline
\end{tabular}

Each character integrated in the target class with CAR. Each cycle required one meeting and each learning method carried out twice. During the cycle, the researcher observed integration process continuity and the teaching and learning process in the classroom during the study. We referred to the Spiral Model of Kemmis and Taggart [16]. The model could be seen in figure. 1 .

The following is describing each character developed and its cycle:

\section{A. Responsibility}

The learning method used to integrate the character of responsibility in the classroom was discussion. Discussion is a process of seeing two or more people interacting verbally and facing each other about goals or targets that determined through the exchange of information, maintains opinions, or problem solving. While the discussion method is a way of presenting learning material where the teacher gives the opportunity to students (groups of students) to hold scientific discussions to gather opinions, make conclusions, or arrange various alternative solutions to a problem [17]. The discussion method is the interaction between students and students or students with teachers to analyze, solve problems, explore, and debate certain topics or problems [18]. 


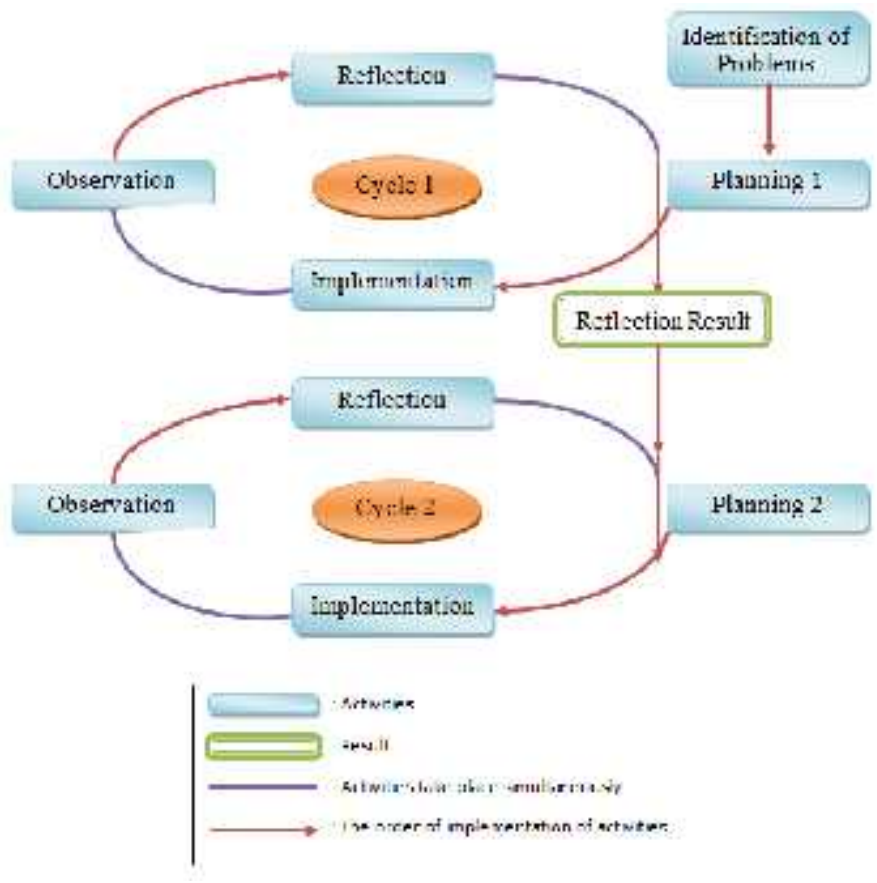

Fig. 1. Research Cycle in CAR

At CAR, the cycle involved includes (1) identification of the problem; (2) planning; (3) implementation; (4) observation; (5) reflection; (6) results of reflection; and return to the beginning for the 2 nd cycle. The result of reflection in cycle 1 was that students had difficulty distinguishing between the characteristics of watch keeping and crew roles. The partner teacher gave feedback after the 1st cycle takes place. The result of his reflection was the understanding of the character of responsibility with the discussion method would be better if the method changed slightly to the group discussion method. Furthermore, each group would present their opinions and examples of manifestation of the responsibilities of each role on the ship.

Researchers did the planning for cycle 2 on integrating character of responsibility. The result of reflection in cycle 2 was that students understand and believe that responsibility must hold by the crew for the voyage to do well. The results validated by observations.

\section{B. Discipline and Leadership}

We used Problem Based Instruction (PBI) to integrate discipline and leadership character. Problem based instruction is a learning model that can arouse students' understanding of problems, an awareness of gaps, knowledge, the urge to solve problems, and the perception that they are able to solve these problems [19]. We chose the PBI method because this method involves students to solve the problems being faced. In addition, this method also requires students' higher thinking skills. ESP for Maritime English learning material used was the organizational of a ship crew.

The results of reflection obtained in cycle 1 of the character of discipline and leadership were students difficulty in making displays of problem solving that made when the ship was in an emergency condition due to presence of shiploads containing hazardous chemicals. Students have not been able to find the cause of the conditions that arise, so the ship was in a dangerous situation.

Based on the results of reflection on cycle 1, the researcher made planning cycle 2 with the same method with different problems. However, there was a slight difference in this cycle 2 PBI method. Researchers used audio-visual learning media, with the aim of students viewing the video. The video told the ship's emergency conditions and the ship's problems at that time. The results of cycle 2 reflection showed an increase in students' understanding of importance of the character of discipline and command unity in dealing with emergencies on board. The character of leadership becomes very important in shipping.

\section{Communication}

The learning method used in integrating communication characters was the command style. The topic discussed was communication at sea. The partner teacher carries the radio communication equipment used on the ship to prove how communication on board carried out. Plan the cycle 1 of CAR to integrate communication characters carried out together with partner teachers. Teacher made all decision during the meeting. Students improved their way to communicate on the ship by imitating and remembering through appearance. The subject divided into parts which could be replicated. Teacher partner gave exemplify model and expected students to emulate him. The result of cycle 1 reflection was that it required a lot of time to complete the task. Thus in cycle 2 there was enough time to prepare all students to complete the given task.

The communication system on the ship does not only use international codes such as Morse code, flag code and navigation lights which are only used at certain times. At present, communication on ships, between ships, and between ships and ground-based transmitting stations uses radios. Radio communication used on ships is no different from on land. One of the efforts to prevent ship accidents and other losses in shipping is to carry out scouting services. Because the scout considered a navigator who is very knowledgeable about the condition and nature of the local waters as well as his ability to control the ship through his advice or command to the skipper so that the ship can navigate a waters safely.

\section{CONCLUSION}

The use of classroom action research (CAR) integrated character education in this study helped researchers understand the problems that arise in language learning in the classroom. But CAR has not been able to give complete results if the observation and interview data collection techniques were not carried out in-depth. With in-depth observations and interviews, the researchers found that integrating character education in the classroom on various subjects would give most results if the school integrates character education into school culture.

The research concluded that CAR indeed helps teachers finding the right learning methods in English for Specific Purpose for Maritime. 


\section{ACKNOWLEDGMENT}

The work was ostensibly supported by The Ministry of Research Technology and Higher Education of the Republic of Indonesia who has funded this research fully.

The Authors also would like to acknowledge Mr. Fahmi, the headmaster of SMK Pelayaran Samudera Indonesia Medan, teachers and students for their support as the School Partner in this research.

\section{REFERENCES}

[1] Asmani, Jamal Ma'mur, Buku Panduan Internalisasi Pendidikan Karakter di Sekolah, Yogyakarta: DIVA Press, 2011.

[2] Widodo, Hendro dan Avanti Vera Risti P. Pendidikan Karakter Holistik Integratif di PAUD Terpadu 'Aisyiyah Nur'aini Ngampilan Yogyakarta. Al-Athfal: Jurnal Pendidikan Anak. Vol 3 (2), 2017.

[3] Puspitaningsih, A.I., dan Sugeng, Bambang. Implementasi Pendidikan Karakter Pada Kegiatan Pembelajaran Bahasa Inggris di SMKN 1 Kandangan Kalimantan Selatan. Jurnal LingTera,Vol. 1, Nomor 1, 2014.

[4] Suyanto dan M.S Abbas, Wajah dan Dinamika Pendidikan Anak Bangsa, Yogyakarta: Adicita Karya Nusa, 2009.

[5] Liao, Y.H., Chen, Y.L., Chen, H.C., \& Chang, Y.L., Infusing creative pedagogy into an English as a foreign language classroom: Learning performance, creativity, and motivation, Thinking Skills and Creativity Journal, vol. 29, Sept 2018, pp: 213-223.
[6] Octavita, R.A.I., and Ria S., Integrasi Pendidikan Berkarakter Dalam Pembelajaran Bahasa Inggris, Jurnal Terapan Abdimas, vol 2, Januari 2017, pp. 33-40.

[7] Ananda Rusydi, Rafida T., and Sharum, Penelitian Tindakan Kelas, Ciptapustaka Media, Bandung, 2015.

[8] Triyono, Penelitian Tindakan Kelas: Apa dan Bagaimana Melaksanakannya?, dipresentasikan pada Seminar Guru-guru se UPDT Sumpiuh, Banyumas, 24 Agustus 2008

[9] Eliawati, Titim and Dina I.H., Teacher Leadership In The Class On Student Character Building, MELT Journal, vol 3, Issue 2, December 2018.

[10] Hopkins, David, A Teacher's Guide to Classroom Research, Philadelphia: Open University Press, 1993.

[11] Creswell, John W, Research Design, California: Sage Publ., Inc., 1994.

[12] Ary, Donald, et al., Introduction To Research In Education, Canada: Nelson Education, Ltd. 2010.

[13] Wiriaatmadja, Rochiati, Metode Penelitian Tindakan Kelas, Remaja Rosdakarya, Bandung, 2019.

[14] Sudikin, et al. Manajemen Penelitian Tindakan Kelas, Insan Cendekia Surabaya, 2002.

[15] Mahmud dan T Edi P., Penelitian Tindakan Kelas (Teori dan Praktik), Bandung, Tsabita, 2008.

[16] Kemmis S dan Mc Taggart R, The Action Research Planner, Victoria Dearcin University Press: 1988

[17] Tukiran, Taniredja, dkk., Model-Model Pembelajaran Inovatif, Bandung: Alfabeta, 2011

[18] Aqib, Zainal, Model-Model, Media, dan Strategi Pembelajaran Kontekstual (Inovatif), Bandung: Yrama Widya, 2014.

[19] Rusman, Model-model Pembelajaran (Mengembangkan Profesionalisme Guru), Jakarta: Raja Grafindo Persada, 2014. 